This is an author produced version of a paper published in Environmental Management.

This paper has been peer-reviewed and is proof-corrected, but does not include the journal pagination.

Citation for the published paper:

Efrem Garedew, Mats Sandewall \& Ulf Söderberg. (2012) A Dynamic Simulation Model of Land-Use, Population, and Rural Livelihoods in the Central Rift Valley of Ethiopia. Environmental Management. Volume: 49, Number: 1, pp 151-162.

http://dx.doi.org/10.1007/s00267-011-9783-4.

Access to the published version may require journal subscription.

Published with permission from: Springer-Verlag.

Standard set statement from the publisher:

The original publication is available at www.springerlink.com at http://link.springer.com/article/10.1007/s00267-011-9783-4?null

Epsilon Open Archive http://epsilon.slu.se 


\title{
A Dynamic Simulation Model of Land-Use, Population, and Rural Livelihoods in the Central Rift Valley of Ethiopia
}

Efrem Garedew $^{1,2} \cdot$ Mats Sandewall $^{2} \cdot$ Ulf Soderberg $^{2}$

\begin{abstract}
The dynamic interactions between society and land resources have to be taken into account when planning and managing natural resources. A computer model, using STELLA software, was developed through active participation of purposively selected farm households from different wealth groups, age groups and gender within a rural community and some members of Kebelle council. The aim of the modeling was to study the perceived changes in land-use, population and livelihoods over the next 30 years and to improve our understanding of the interactions among them. The modeling output is characterized by rapid population growth, declining farm size and household incomes, deteriorating woody vegetation cover and worsening land degradation if current conditions remain. However, through integrated intervention strategies (including forest increase, micro-finance, family planning, health and education) the woody vegetation cover is likely to increase in the landscape, population growth is likely to slow down and households' income is likely to improve. A validation assessment of the simulation model based on historical data on land-use and population from 1973 to 2006 showed that the model is relatively robust. We conclude that as a supporting tool, the simulation model can contribute to the decision making process.
\end{abstract}

Keywords: Forest increase; Household income; Land-use; Land degradation; STELLA software

\footnotetext{
${ }^{1}$ School of Forestry, Wondo Genet College of Forestry \& Natural Resources, Hawasa University, Shashemene, P.O. Box 128, Ethiopia. Email: efrem.garedew@yahoo.com.

${ }^{2}$ Department of Forest Resource Management, Swedish University of Agricultural Sciences, Umea 901-83, Sweden
} 


\section{Introduction}

There is a strong and complex relationship between natural resources and rural livelihoods. Rural people in low income countries depend on the availability and access to natural resources for supporting their livelihoods (Ellis and Allison 2004). A livelihood comprises the assets (natural,

physical, human, financial and social capital), the activities and the access to these (mediated by institutions and social relationships) that together determine the living gained by the individual or household (Ellis 2000).

The increasing global concerns about the sustainable management of natural resources which followed the UN summit in Rio de Janeiro in 1992 have not visibly reduced the pace of deforestation in the tropics, which is caused by a complex mixture of demographic, economic, technological, cultural and institutional factors (Hartemink et al. 2008; Lambin et al. 2003). In the international discourse on natural resources conservation, there are diverse relationships between conservation strategy and poverty reduction that reflect conflicting paradigm positions in the current debate conservation (Adams et al. 2004). The proponents of the so-called " zero conservation"' or 'fortress conservation'” approach advocate protection measures that seeks to exclude local people from natural resources (Hutton et al. 2005; Sanderson and Redford 2003). However, others still equally have different views, community based management projects can make both development and conservation economically viable and attractive for the local communities to maintain biodiversity and integrity of nature (Singh 2008; Sunderland et al. 2008). Furthermore, Robbins et al. (2006) and Romero and Andrade (2004) suggested that the exclusion of communities from conservation ultimately leads to social conflict and noncompliance with conservation-related regulations (Chan et al. 2007). The combining of participatory modeling and livelihood studies could contribute to sustainable natural resource management and livelihood improvement by building shared understanding of critical issues and helping to focus on conservation and development interventions (Campbell et al. 2008).

Africa is already a region under pressure from climate stresses and is highly vulnerable to the impacts of climate change (UNFCCC 2007). Thus, African countries working in the conservation-development nexus need to take active part in the current global and regional processes on climate change adaptation. 
Ethiopian subsistence agriculture is heavily dependent on rain-fed production. The erratic nature of rainfall leads to reduced crop production. The main reason is the daily, seasonal and inter-annual rainfall variability (Segele and Lamb 2005). In Ethiopia, widespread land degradation has led to severe challenges for the people (Amsalu and de Graaff 2006; Argaw 2005; Mahmud et al. 2005; Taddese 2001). Socio-economic and institutional factors, such as population pressure, poverty and land tenure arrangements are the main contributors to land degradation. Population growth raises the demand for subsistence cropland and for biomass (fuel and fodder). Both are leading to deforestation. People's lack of access to alternative sources for livelihood exacerbates this, and, therefore increases the problems of erosion and nutrient depletion (Haile 2004; Nyssen et al. 2009).

In Ethiopia, land tenure is a disputed issue. All rural land is owned by the state and part of this land is allocated to farmers on a use-right basis (Bogale et al. 2006). The rural land reform policy strictly prohibits the transfer of land by sale or mortgage. However, it does allow transfer of use-right in the form of gift, inheritance, restricted leasing and sharecropping (Crewett et al. 2008). Most debates and studies on land ownership of the state mainly revolve around questions of insecurity (redistributions) of landholdings, degradation of soil quality, unsuitable land use practice and fragmentation of farms. The federal government and the regional states have started a process of land registration and certification to address farmers rural land insecurity (Deininger et al. 2008).

The rapidly growing population in Ethiopia adds approximately two million people per year and population is predicted to be more than double current levels by the year 2050 (United Nations Population Division 2009). Internal migration in Ethiopia is high and associated with education, demographic, economic and environmental and security reasons (Mberu 2006). Historically rural-to-urban, urban-to-rural and rural-to-rural migration has varied dramatically with famines and political reforms (Ezra 2001; Tegenu 2003). Households living in the rural areas such as the Rift Valley are faced with a number of constraints, including erratic rainfall, recurrent droughts, rapid population growth, deforestation, soil degradation, food insecurity and low education (Garedew et al. 2009). People are the main agents of environmental degradation and they are also the victims. Villagers who were involved in previous research with the same authors acknowledged the importance of a continuous discussion on the sustainable use of forests and other natural resources, which enabled them to move towards more sustainable 
practices. Farmers realized that they over used the local woodland. Recurrent drought and the constrained subsistence agriculture drove people to overuse the forest as safety net strategy, because other livelihood options than dry-land agriculture are very limited in the study area. High population increase would have a major impact on the remaining forests. Further, we experienced that farmer's still perceive land tenure as insecure. The establishment and successful implementation of a forest restoration site by the Forestry and Natural Resource College and an action research project on the community land has had a positive impact on the behavior of the surrounding farmers towards forest increase. Accordingly, people are increasingly aware of the importance of woodland forests as a safety net during recurrent droughts and of the need to manage them sustainably. During discussions, villagers have also expressed interest in increasing the forest cover and forest area on the landscape. Some of them already have woodlots around their homesteads which is an encouraging drive to others.

Further depletion of the environment, low agricultural production and worsening socioeconomic conditions, including rapid population growth could be foreseen if current trends remain. The objective of this study is to explore a participatory dynamic simulation modeling approach based on a dialogue with farmers in order to test different development strategies (scenarios). The approach would include the generation of forward projections (from 20062036) of land-use, population and income under various assumptions discussed with the farmers and should contribute to the debate on how to address social-economical and environmental changes.

\section{Material and Methods}

\section{Study Area}

The study area is “'Keraru’” Kebelle (Kebelle is the lowest administration unit in the government structure) in the “Arsi-Negele”' district of Oromiya National Regional State located between 205 and $210 \mathrm{~km}$ south of Addis Ababa (Fig. 1). It covers 2932 ha and represents a semi-arid flat land of the district's lowland climatic zone and is situated below 1800 m ASL (Garedew et al. 2009). The nearby climate data from the National Meteorological Services Agency for the years’ 19722005 shows that the annual rainfall ranges between $264 \mathrm{~mm}$ and 968 (the mean is $710 \mathrm{~mm}$ ), while the mean annual minimum and maximum temperatures are 13.5 and $27.7{ }^{\circ} \mathrm{C}$, respectively. 


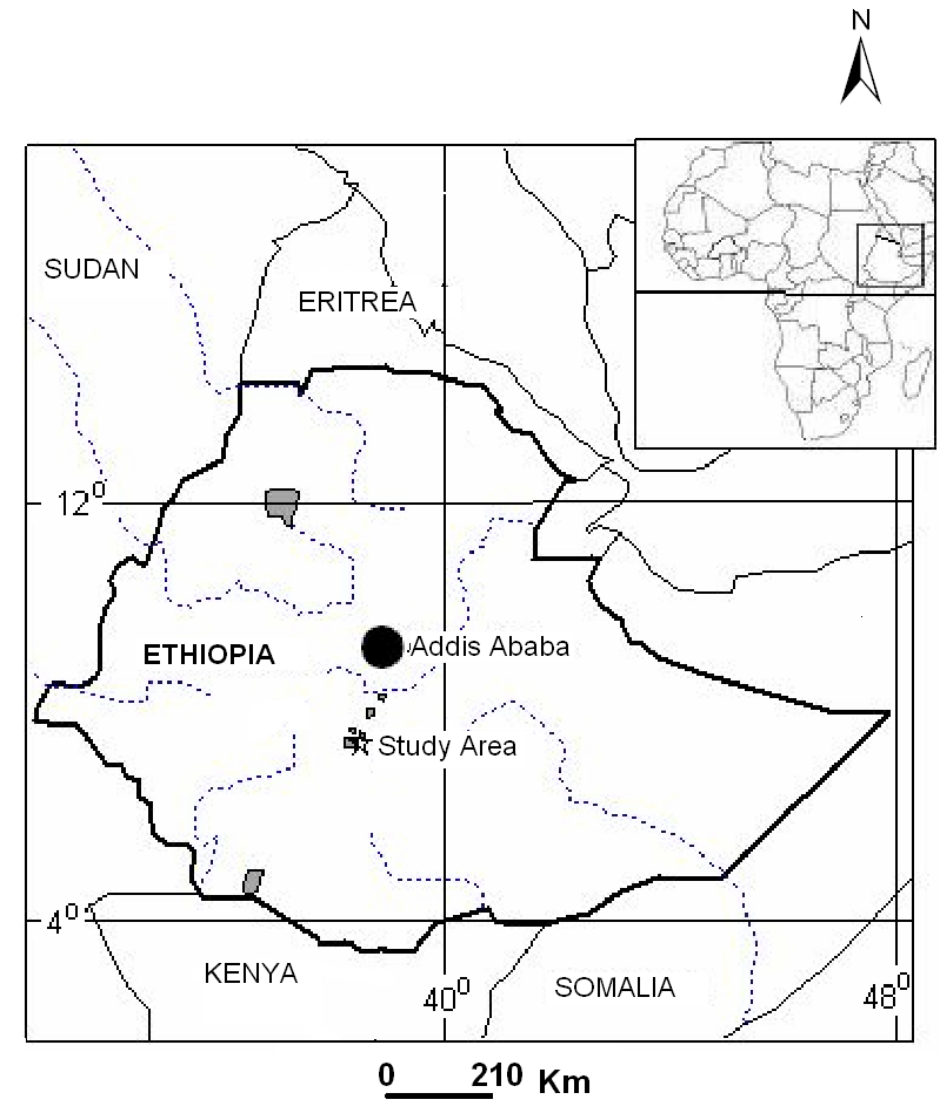

Figure 1 Map of Ethiopia, shows location of the study area

The study area had a population of 3647 in 2004, the population density was 124 persons per $\mathrm{km} 2$, the annual population growth rate was $2.5 \% \pm 0.2$ and the rural-urban migration was low (Garedew et al. 2009). The people in the area are farmers, most of them from the Oromo ethnic group, who practice Islam and live in polygamous families. The mainstay of their livelihoods is agriculture including mixed livestock raising and rain-fed crop production. Major crop types grown are maize, wheat and tef (Eragrostis tef). The government extension service is minimal. The natural woody vegetation was dominated by woodland's and wooded-grassland of Acacia trees, but the area has experienced a rapid deforestation at a rate of $1 \%$ per year with cropland successively replacing woodland and wooded grassland Acacia forests (Garedew et al. 2009).

Methods 
We based the participatory modeling on an approach described by the Center for International Forestry Research (CIFOR) (http://www.cifor.cgiar.org/conservation/_ref/research/index.htm). A system dynamics model was built using the stock- and- flow model software (STELLA v.8) with an icon based interface and availability of array functions (Costanza and Voinov 2001; High Performance Systems Inc. 1996). System dynamics is a concept that considers the dynamic interaction between the elements of the studied system and can help to understand their behavior over time, build models, identify how information feedback governs the behavior of the system and develop a strategy for better management of the studied system (Doerr 1996).

The study was conducted in 2009 using data inputs and assumptions from a previous study (Garedew et al. 2009), farmers and experts from the district Agricultural \& Rural Development Bureau were involved, unpublished data and other sources (Tables 1, 2 and 3). The present study involved a process of model building with active participation of 20 informants (focus group) representing purposively selected households from diverse categories of wealth, age and gender within the community to obtain diverse information. The selection was made with the help of the Kebelle council by picking up those individuals who had formal education and considered reasonably able to understand the topics, express feelings, opinions and perspective on the situations.

Some members of the Kebelle council were also involved in the study. Repeated meetings and discussions were also made with the entire community to triangulate the data obtained from the focus group. The purpose was to obtain good understanding of their objectives in resource management and building on their knowledge about the trends of the local environment and livelihood (Sayer and Campbell 2004). Wherever data was lacking, information was provided through the focus group dialogue and consensus. This helped to improve the input data of the different sectors of the model for exploring reasonable socio-economical and environmental pathways.

Three main scenarios were elaborated. The first one was named ' business as usual”' and did not assume any significant change in the future conditions or stakeholders' behavior. In the second scenario, “'strategies for socio-economic development”, a number of assumptions 
reflecting government (MoFED 2007) and local efforts for socioeconomic change, including micro-finance, better family planning, better health and better education services, were made. 
Table 1 Data inputs and assumptions for 'land-use model sector' in studying the trends of land-use using various scenarios

\begin{tabular}{|c|c|c|c|}
\hline \multirow[t]{2}{*}{ Data } & \multicolumn{2}{|l|}{ Assumption } & \multirow[t]{2}{*}{ Data Sources } \\
\hline & With forest increase strategy & $\begin{array}{l}\text { Without forest } \\
\text { increase strategy }\end{array}$ & \\
\hline $\begin{array}{l}\text { Total area }=2932 \text { ha } \\
\text { Farmland }(\mathrm{FL})=57.6 \% \\
\text { Grassland }(\mathrm{GL})=26.2 \% \\
\text { Woodland }(\mathrm{WL})=6.6 \% \\
\text { Shrubland }(\mathrm{SL})=5 \% \\
\text { Wooded-grassland } \\
(\mathrm{WGL})=1.6 \% \\
\text { Bareland }(\mathrm{BL})=1.6 \% \\
\text { Settlement }(\mathrm{S})=1.4 \%\end{array}$ & 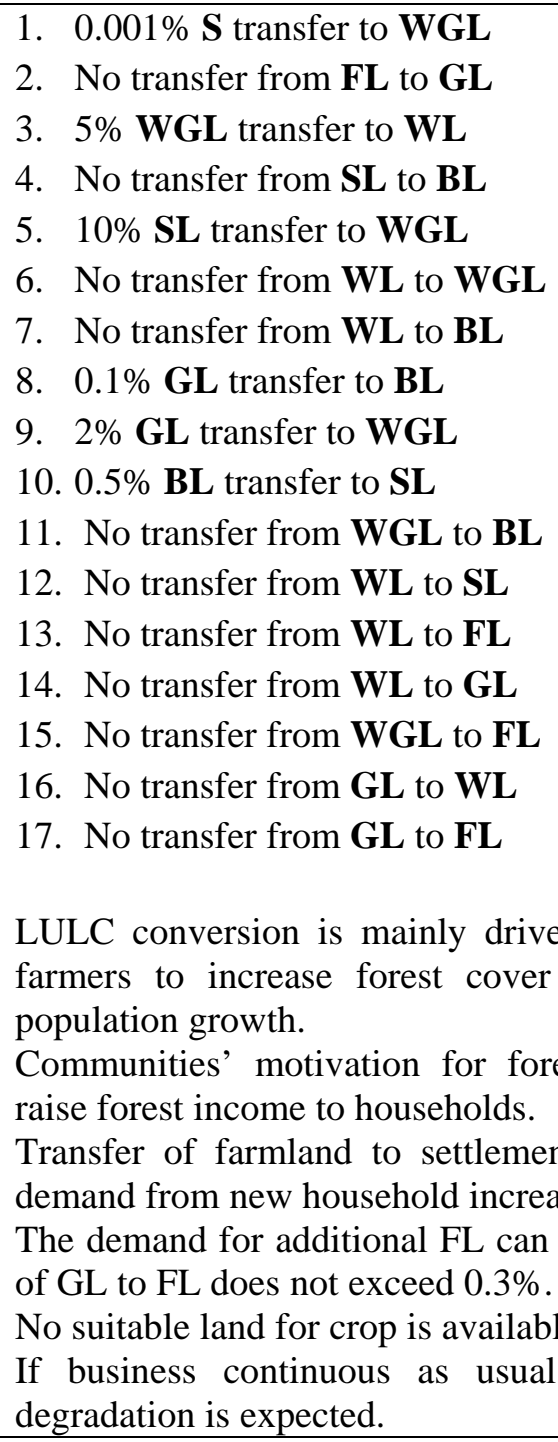 & $\begin{array}{l}\text { 1. No transfer } \\
\text { 2. } 0.3 \% \text { transfer } \\
\text { 3. } 0.1 \% \text { transfer } \\
\text { 4. } 1 \% \text { transfer } \\
\text { 5. No transfer } \\
\text { 6. } 5 \% \text { transfer } \\
\text { 7. } 0.5 \% \text { transfer } \\
\text { 8. } 1 \% \text { transfer } \\
\text { 9. } 0.7 \% \text { transfer } \\
\text { 10. No transfer } \\
\text { 11. } 0.5 \% \text { transfer } \\
\text { 12. } 0.2 \% \text { transfer } \\
\text { 13. No transfer } \\
\text { 14. } 2 \% \text { transfer } \\
\text { 15. No transfer } \\
\text { 16. } 0.5 \% \text { transfer } \\
\text { 17. No transfer } \\
\text { by the motivation of } \\
\text { and area, and by the } \\
\text { increase could help } \\
\text { is based on the area } \\
\text { es. } \\
\text { torease but the transfer } \\
\text { further environmental }\end{array}$ & $\begin{array}{l}\text { Garedew et } \\
\text { al., 2009, with }\end{array}$ \\
\hline
\end{tabular}

The third scenario, “forest increase”" was put in focus and modeled as a pathway for restoring the woody vegetation in the landscape through an area closure strategy (e.g., by excluding cattle).

Table 2 Data inputs and assumptions for 'human population model sector' in studying the trends of population using various scenarios 


\begin{tabular}{|c|c|c|}
\hline Data & Assumption & Data Sources \\
\hline $\begin{array}{l}\text { Population size }=3840 \text { in } \\
2006\end{array}$ & & $\begin{array}{l}\text { Data interpolation } \\
\text { Garedew et al., } 2009\end{array}$ \\
\hline \multirow[t]{5}{*}{$\begin{array}{l}\text { Growth rate }=2.5 \% \\
\text { Household size }=6\end{array}$} & $\begin{array}{l}\text { Population increase is mainly determined by } \\
\text { birth }\end{array}$ & $\begin{array}{l}\text { Garedew et al, } 2009 \text { 2006/07 } \\
\text { HH survey, and authors } \\
\text { calculation }\end{array}$ \\
\hline & $\begin{array}{l}\text { With better family planning strategy, } \\
\text { projected birth rate=3.0\% while current birth } \\
\text { rate }=3.86 \%\end{array}$ & $\begin{array}{l}\text { World Population Prospects, } \\
2008 \text { revision }\end{array}$ \\
\hline & $\begin{array}{l}\text { With better health service, death rate }=0.85 \% \\
\text { while with current health service death } \\
\text { rate }=1.2 \%\end{array}$ & \\
\hline & $\begin{array}{l}\text { Emigration is negligible with the current } \\
\text { educational status while with better education, } \\
\text { Emigration is assumed to be } 0.3 \%\end{array}$ & \\
\hline & $\begin{array}{l}\text { We also assumed, Emigration will likely } \\
\text { occur due to landlessness, } 0.1 \%\end{array}$ & \\
\hline
\end{tabular}

Woodland forest is a source of firewood, charcoal, construction material for the local farmers' consumption, and also fodder for livestock. This scenario was initiated by the farmers themselves in order to express the availability of wood for households' consumption, improve livestock productivity and reduce soil erosion (water and wind) and resuming of additional forest cash income for livelihood. Currently, the woodland forest is almost disappearing and the important forest income and biomass collection (firewood and charcoal for sale and consumption and livestock fodder) are shrinking rapidly.

The model structure included several sub-models or sectors representing components of the socio-economical and environmental systems. These are land-use, human population, rainfall and a variety of incomes from crop and livestock production and non-farm activities (Fig. 2). The model simulated all variables over a period of 30 years. In the model the land-use stock is described as a function of changes in different categories of land-uses, human population dynamics and forest increase scenario. Land-use data inputs and assumptions are presented in Table 1. Those assumptions were based on historically observed trends and a discussion with the local farmers on what would be reasonable in the dynamics of land-use. 


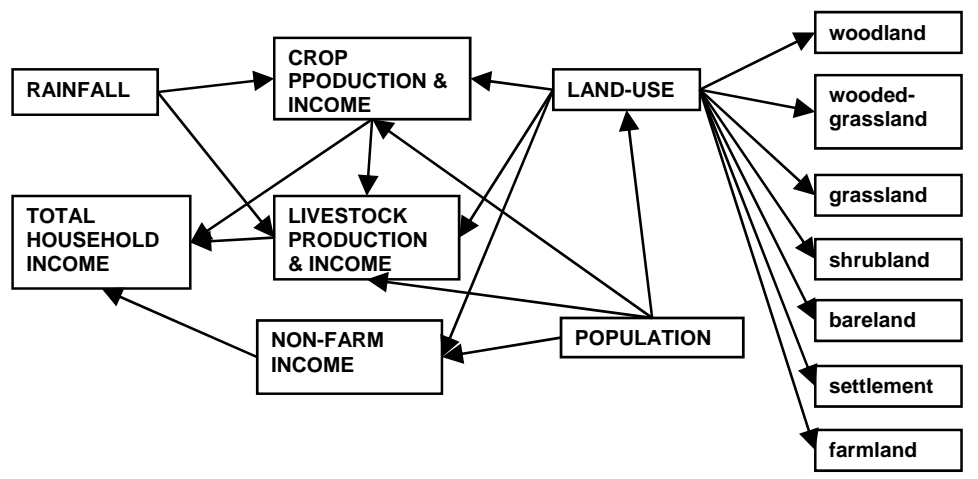

Figure 2 The structure of the model

The human population size is described as a function of growth rate, death rate and emigration. The population growth is influenced by the proposed family planning, health and education scenarios. The livestock number and livestock income are modeled as a function of the estimated losses and increases in livestock number, the carrying capacity (feed resources) of the area in terms of tropical livestock unit (TLU), human population dynamics and rainfall. Livestock carrying capacity was calculated based on the total animal feed available from different sources: grassland, crop residues and forest land (Table 3). Crop production is based on farm size of the households, human population dynamics, the variability of rainfall and the availability of micro-finance. Furthermore, non-farm income is based on the human population and land-use dynamics, the availability of micro-finance and educational conditions.

The model was built for an average household whose farm size is 1.5 ha, with a cropping area of maize (65\%), wheat (25\%) and tef (10\%). The estimated average annual crop productivity of maize was 1.25 ton/ha (varying between 0.7 and 2.2) while wheat was 1.1 ton/ha (varying between 0.5 and 1.4) and tef 0.5 ton/ha (varying between 0.2 and 0.7 ). On the farmland, food crops are grown for subsistence and cash needs of the farming households.

Table 3 Data inputs and assumptions income and rainfall' model in studying the trends income and rainfall using various scenarios 
1. Current crop income $=60 \%$ With micro-finance strategy farmers could able to use modern inputs (chemical fertilizer and improved seeds), we assumed crop productivity is likely doubled. Thus, crop income is increasing

2. Current income $=15 \%$ livestock Livestock income is dependent on the number of livestock owned by each household and the amount of available fodder/feed.

Thus, the number of average livestock for the household was modelled based on the total carrying capacity of the area in terms of number of tropical livestock unit (TLU).

In turn the total carrying capacity is calculated based on the total animal feed available from different sources: grassland and crop residues (both are mainly dependent on rainfall amount and distribution) and forest land:

cc_tlu $=$ initial number household $*$ cc_tlu estimate * cc reduction. cc_tlu estimate $=$ initial total tlu $* 2$; cc reduction $=$ total $\mathrm{f} /$ initial total $\mathrm{f}$; total $\mathrm{f}=\left(\right.$ area_gl $\left.* \mathrm{gl} \_\mathrm{fr} / \mathrm{ha}\right)+\left(\right.$ area_fl $\left.* \mathrm{fl} \_\mathrm{fr} / \mathrm{ha}\right)+$ total sf; initial total $\mathrm{f}=$ (initial area_gl * gl_fr/ha + initial total sf + initial area_fl * fl_fr/ha; total sf $=[$ (land area for maize * yield_maize residues /ha) + (land area_teff *yield _teff residues /ha) + (land area_wheat * yield_wheat residues/ha)]

*number of household.

Where, cc_tlu is the total tlu carrying capacity, $\mathrm{f}$ = animal feed in kg, gl_fr

$=$ animal feed resource from grassland is estimated based on random rainfall, fl_fr $=$ animal feed (biomass) resource from forest land is estimated $600 \mathrm{~kg} / \mathrm{ha}, \mathrm{sf}=$ stover feed and is measured in $\mathrm{kg}$.

With micro-finance use livestock growth rate likely to double, from $0.1 \%$ to $0.2 \%$ for cattle while from $0.5 \%$ to $1 \%$ for goat/sheep and from $0.5 \%$ to $1 \%$ for chicken.

3. Current

non-farm

income $=25 \%$.

Household's involved in at least three non-farm activities.

$14 \%$ households involved in petty trading.

$69 \%$ households involved in forest cash income.

4. The total household income is around 7811 Birr

5. Rainfall
With micro-finance, we assumed that, every year additional 2\% households are likely to become involved in petty trading.

Forest increase assumption is likely to increase cash income from the forest and an additional $2 \%$ of households are expecting to earn this additional income.
Better education is likely to result in $2 \%$ of households earning additional income from remittance.

Annual rainfall, as a random variable based on the minimum (264 $\mathrm{mm}$ ) and maximum (968 $\mathrm{mm}$ ) values, likely influencing agricultural production and the total household income levels. 
Crop net income (both consumption and cash) was calculated by subtracting the estimated crop cost and loss (30\% of total crop income) from the total household crop income. In the study area, an average household owns five cattle, three goat/sheep, one donkey and two chickens which generate household livestock income, including sale of livestock products (mainly milk and eggs), sale of livestock, plough oxen rent, transport rent and consumption uses. All farmers do not have all kind of livestock goods throughout the year but buy and exchange internally for their own use while they also supply to the market. The economic contribution of the livestock sector is considerable and accounts for $15 \%$ of the total household income. In the study, nonfarm income comprises wage labor, forest- based activities, small scale fishing, sale of salt-rich soil for cattle feed, petty trading, sale of sand for construction, sale of traditional drink, government safety net transfer and remittance (little was reported). A household averagely enrolled in at least the three of these non-farm income generation sources. All monetary values are reported in Ethiopian Birr, where USD \$1 =*11.50 in 2009.

Model testing was an essential part of the model development process. If the model is to be used, it should provide relatively accurate information about the system being modeled. In this study, the model could be validated by using land-use data from 1973 and the actual population data of the Kebelle from 1975 as input variables (Garedew et al. 2009) and modeling of the period 1973/75-2006. The resulting simulated land-use values for three occasions (1986, 2000 and 2006) and simulated population values for four occasions (1984, 1994, 2004 and 2006) could then be compared to observed conditions and values derived from Garedew et al. (2009).

\section{Result}

\section{Dynamics in Population}

The population sector model simulates natural population growth annually. Table 4 shows the simulations of population growth based on various intervention strategies, including “business as usual” ' and “'better family planning', “'better health”, “'better education” and a combination of the three latter. Over the simulation period (2006-2036), the total population growth varies between $68 \%$ and $136 \%$ among the simulated strategies. However, when compared to " business as usual”, the scenario “better health”' actually rise population growth (through reduced mortality), while “better family planning”' (implying reduced birth rate), “better education”, 
(meaning increased emigration) and the combined scenario significantly reduce population growth, Apparently, better family planning and the combined scenarios would be the best pathways for a balanced population growth compared to other strategies if considering the carrying capacity and the sustainable use of natural resources.

Table 4 Simulation of human population growth based on different the strategies

\begin{tabular}{llllll}
\hline Years & $\begin{array}{l}\text { Business } \\
\text { as usual } \\
\text { (BAU) }\end{array}$ & $\begin{array}{l}\text { Better } \\
\text { family } \\
\text { planning }\end{array}$ & $\begin{array}{l}\text { Better } \\
\text { health }\end{array}$ & $\begin{array}{l}\text { Better } \\
\text { education }\end{array}$ & $\begin{array}{l}\text { Combined } \\
\text { (without BAU) }\end{array}$ \\
\hline 2006 & 3840 & 3840 & 3840 & 3840 & 3840 \\
2009 & 4143 & 4039 & 4185 & 4106 & 4045 \\
2012 & 4469 & 4249 & 4561 & 4391 & 4261 \\
2015 & 4821 & 4469 & 4971 & 4696 & 4489 \\
2018 & 5201 & 4701 & 5418 & 5021 & 4729 \\
2021 & 5610 & 4945 & 5905 & 5369 & 4981 \\
2024 & 6053 & 5201 & 6435 & 5742 & 5247 \\
2027 & 6529 & 5471 & 7014 & 6140 & 5528 \\
2030 & 7044 & 5755 & 7644 & 6566 & 5823 \\
2033 & 7599 & 6053 & 8331 & 7021 & 6134 \\
2036 & 8197 & 6367 & 9079 & 7508 & 6462 \\
\hline
\end{tabular}

Dynamics in Land-Use

The simulations of the two land-use scenarios "with" and "without" the forest increase strategy were based on assumptions of land-use change as specified in Table 1. The simulation outcome as presented in Table 5 illustrate that small modifications in the assumptions of annual land transfers in the scenario "with forest increase strategy" (as compared to the scenario "'without") gave as an outcome that the area of woodland increased quite considerably (203\%) at the expense of other land-use types over a 30 years period.

Table 5 Simulation of land-use types (ha) based on without (A) and with (B) forest increase strategies

\begin{tabular}{llllllll}
\hline Years & Grassland & Woodland & Shrubland & Wooded-grassland & Bareland & Farmland & Settlement \\
\hline A & & & & & & & \\
0 & 769 & 192 & 145 & 48 & 48 & 1696 & 42 \\
3 & 735 & 174 & 153 & 89 & 72 & 1672 & 45 \\
6 & 707 & 159 & 159 & 123 & 94 & 1650 & 49 \\
9 & 683 & 145 & 163 & 152 & 115 & 1628 & 53 \\
12 & 665 & 134 & 167 & 176 & 134 & 1608 & 57 \\
15 & 650 & 123 & 170 & 196 & 152 & 1589 & 61 \\
18 & 638 & 114 & 172 & 212 & 168 & 1570 & 66 \\
21 & 628 & 106 & 173 & 226 & 184 & 1552 & 71 \\
24 & 621 & 99 & 174 & 237 & 198 & 1536 & 75
\end{tabular}




\begin{tabular}{llllllll}
27 & 615 & 93 & 175 & 247 & 211 & 1519 & 80 \\
30 & 611 & 88 & 175 & 254 & 223 & 1504 & 85 \\
B & & & & & & & \\
0 & 769 & 192 & 145 & 48 & 48 & 1696 & 42 \\
3 & 756 & 214 & 123 & 78 & 44 & 1679 & 45 \\
6 & 745 & 242 & 108 & 97 & 40 & 1660 & 49 \\
9 & 735 & 274 & 96 & 108 & 37 & 1638 & 53 \\
12 & 725 & 309 & 87 & 114 & 34 & 1614 & 57 \\
15 & 716 & 348 & 81 & 116 & 31 & 1587 & 61 \\
18 & 706 & 389 & 76 & 116 & 29 & 1558 & 66 \\
21 & 697 & 433 & 73 & 115 & 26 & 1525 & 71 \\
24 & 688 & 480 & 70 & 113 & 24 & 1490 & 75 \\
27 & 679 & 530 & 67 & 111 & 22 & 1451 & 80 \\
30 & 670 & 583 & 65 & 109 & 20 & 1410 & 84 \\
\hline
\end{tabular}

For the villagers who initially defined what they want to achieve, (e.g., increased woodland) the interesting part (" ‘the result") would be what input data generate that output (e.g., more woodland) and how to go about to harmonize the input data in their daily life situation.

The different rates of population growth in different scenarios affect the settlement area and the farm size per household (see Figs. 3, 4). Overall, the total area of settlements is increasing throughout the simulation period while the increments follow different pattern of pathways for different intervention strategies (Fig. 3). For instance, area of settlement dramatically increases with better health scenario compared to other intervention strategies. While the farm size per household tends to decrease throughout the simulation years irrespective of intervention strategy (Fig. 4). Here also better family planning and the combined scenario options are the best alternative pathways to slowing down the trends of decreasing farm size of households.

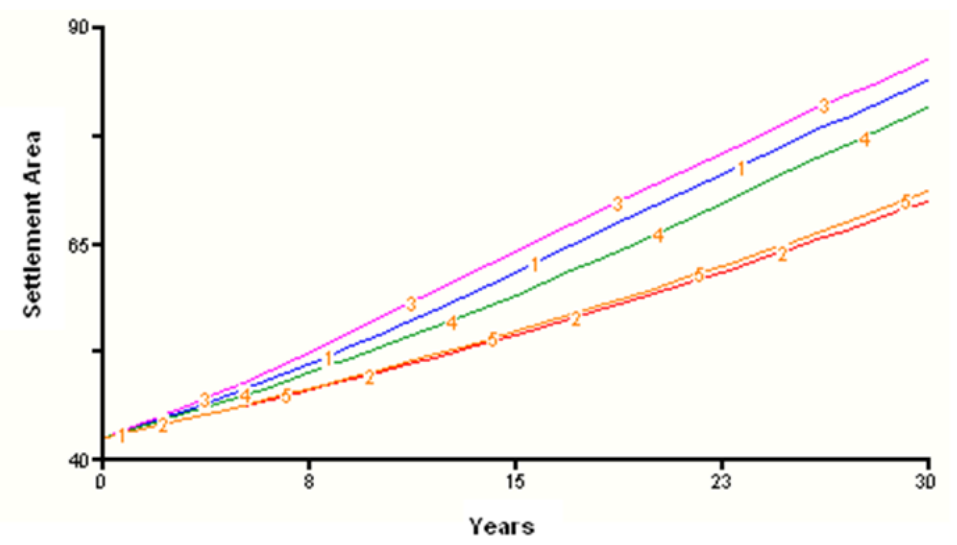

Figure 3 Simulation of settlement areas under five different integrated strategies of scenarios: 1=business as usual, 2=better family planning, $3=$ better health, $4=$ better education, $5=$ combined scenarios $(2,3 \& 4)$ 


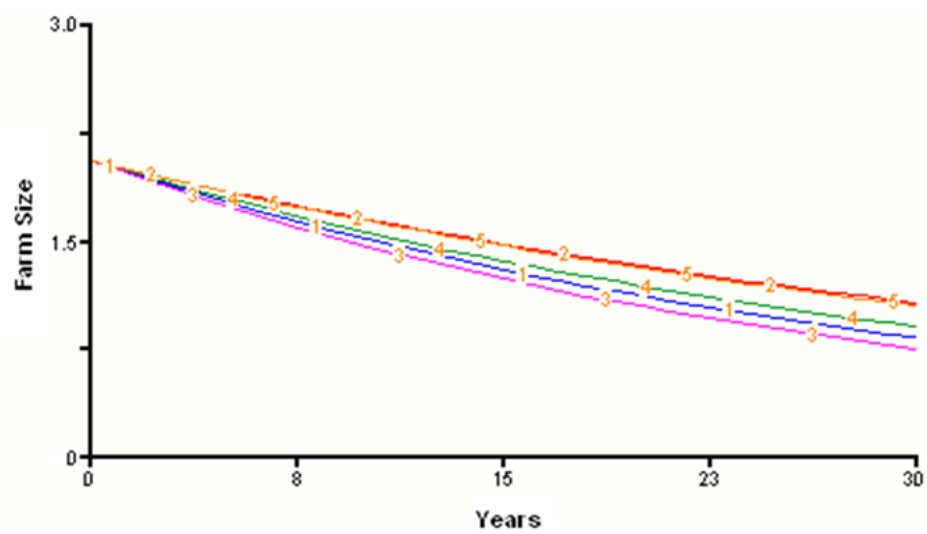

Figure 4 Simulation of per household farm size under five different integrated strategies of scenarios: 1 =business as usual, $2=$ =better family planning, $3=$ better health, $4=$ better education, $5=$ combined scenarios $(2,3 \& 4)$

Livelihood Strategies and Income Dynamics in the Households

Over the last three decades the households have mainly followed an increasingly extensive mixed agricultural livelihood strategy (crop and livestock). Farmers have recognized that recurrent droughts, erratic rainfall and soil degradation have influenced the agricultural productivity and food security. As those droughts occurred and the population increased, the forest cover has decreased when farmers tried to compensate the declining crop productivity by opening new croplands for subsistence agriculture. At this stage no more suitable land is left for cropland expansion. The demand for land by new households has also increased and as a result farm size per household is diminishing. During normal rainfall seasons high costs for agricultural inputs (chemical fertilizer and improved seeds) and lack of plow oxen exacerbate the challenges for the crop production sector. Households' efforts to diversify incomes through non-farm economic activities in order to buy food for the dry season can only provide marginal opportunities to fill the food gap.

The simulation of the average household income from crops and livestock (Table 6) followed a range of patterns between different intervention strategies. For agricultural income, all of the intervention strategies, both the microfinance and the combined scenarios, considerably improved household incomes in the long-term but they had no regular patterns over the separate years of simulation. The reason is that households' income is regulated by the amount of income 
generated from agricultural production, which is largely dependent on the amount of rainfall and its distribution within the growing season, since agriculture is mostly rain-fed in the study area.

Table 6 Simulation of farm household incomes (Birr) based on different strategies

\begin{tabular}{|c|c|c|c|c|c|c|}
\hline \multirow[t]{2}{*}{ Years } & \multicolumn{2}{|c|}{ Crop income } & \multicolumn{4}{|c|}{ Livestock income } \\
\hline & $\begin{array}{l}\text { Business } \\
\text { as usual } \\
\text { (BAU) }\end{array}$ & $\begin{array}{l}\text { Micro- } \\
\text { finance }\end{array}$ & $\begin{array}{l}\text { Business } \\
\text { as usual } \\
\text { (BAU) }\end{array}$ & $\begin{array}{l}\text { Forest } \\
\text { increase }\end{array}$ & $\begin{array}{l}\text { Micro- } \\
\text { finance }\end{array}$ & $\begin{array}{l}\text { Combined } \\
\text { (without } \\
\text { BAU) }\end{array}$ \\
\hline 2006 & 3248 & 7307 & 2562 & 2562 & 2562 & 2562 \\
\hline 2009 & 3518 & 8457 & 3043 & 3043 & 3175 & 4657 \\
\hline 2012 & 4480 & 8681 & 3054 & 3054 & 3496 & 4093 \\
\hline 2015 & 3297 & 9898 & 2790 & 2790 & 3195 & 5110 \\
\hline 2018 & 3702 & 10270 & 2917 & 2917 & 3581 & 4342 \\
\hline 2021 & 3869 & 9570 & 3007 & 3007 & 3300 & 3754 \\
\hline 2024 & 5075 & 8650 & 2998 & 2998 & 3297 & 4008 \\
\hline 2027 & 2844 & 11528 & 2535 & 2535 & 2742 & 4268 \\
\hline 2030 & 3127 & 8805 & 2685 & 2685 & 2965 & 3810 \\
\hline 2033 & 5409 & 5668 & 2405 & 2405 & 2510 & 3793 \\
\hline 2036 & 2796 & 7017 & 2188 & 2188 & 2576 & 3465 \\
\hline
\end{tabular}

A rainfall model was produced by a random generator providing annual rainfall values between $250 \mathrm{~mm}$ and $950 \mathrm{~mm}$. The simulated output shows that the magnitude of agricultural income (in particular income from crops) per household varies with the amount of rainfall in the area (Fig. 5).

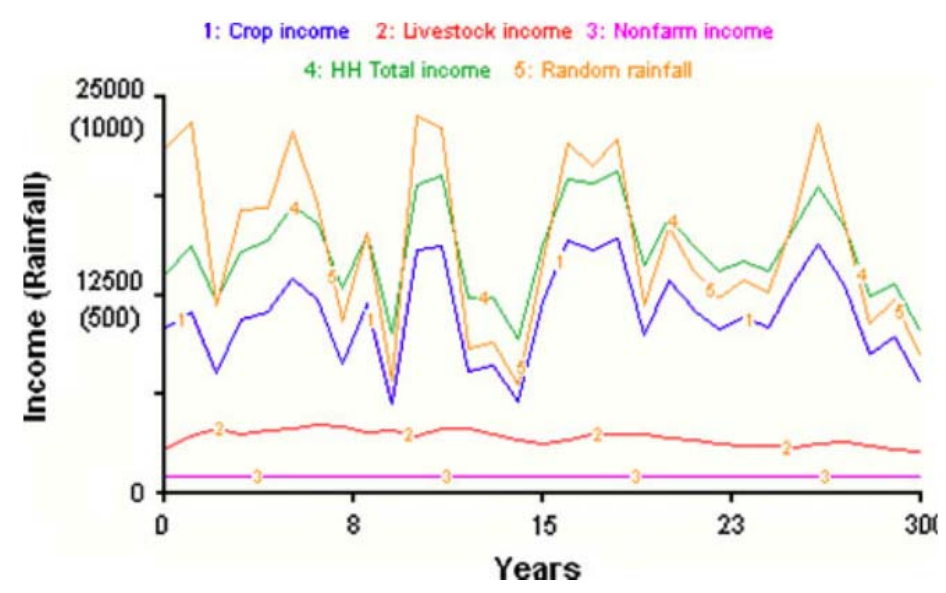

Figure 5 Relationships between the simulated rainfall $(\mathrm{mm})$ and household income under the microfinance strategy

On the other hand, nonfarm income (Table 7) was constant throughout the simulation period at a level specific for each of the strategies. Informants reported that in the past many households had been involved in forest activities and generate substantial non-farm income from sale of 
firewood, charcoal and other forest-based products. As an example, $69 \%$ of the households of the study are extracting some income from the remnant Acacia forest. Hence, the modeling output showed that there would be an increasing non-farm income through the "forest increase" strategy and this was simulated to be doubled when compared to the "business as usual", strategy.

Table 7 Simulation of non-farm household income (Birr) based on different strategies

\begin{tabular}{llllll}
\hline Years & $\begin{array}{l}\text { Business } \\
\text { as usual } \\
\text { (BAU) }\end{array}$ & $\begin{array}{l}\text { Forest } \\
\text { increase }\end{array}$ & $\begin{array}{l}\text { Micro- } \\
\text { finance }\end{array}$ & $\begin{array}{l}\text { Better } \\
\text { education }\end{array}$ & $\begin{array}{l}\text { Combined } \\
\text { (without } \\
\text { BAU) }\end{array}$ \\
\hline 2006 & 795 & 1230 & 811 & 796 & 1247 \\
2009 & 795 & 1230 & 811 & 796 & 1247 \\
2012 & 795 & 1230 & 811 & 796 & 1247 \\
2015 & 795 & 1230 & 811 & 796 & 1247 \\
2018 & 795 & 1230 & 811 & 796 & 1247 \\
2021 & 795 & 1230 & 811 & 795 & 1247 \\
2024 & 795 & 1230 & 811 & 795 & 1247 \\
2027 & 795 & 1230 & 811 & 795 & 1247 \\
2030 & 795 & 1230 & 811 & 795 & 1247 \\
2033 & 795 & 1230 & 811 & 795 & 1247 \\
2036 & 795 & 1230 & 811 & 795 & 1247 \\
\hline
\end{tabular}

\section{Model Validation}

Figures 6, 7, 8 and 9 show the comparisons between the historical development and simulated model for changes in population size and areas of woodland, wooded-grassland and farmland. Generally, the simulated curves approximately match the historical development of all studied variables.

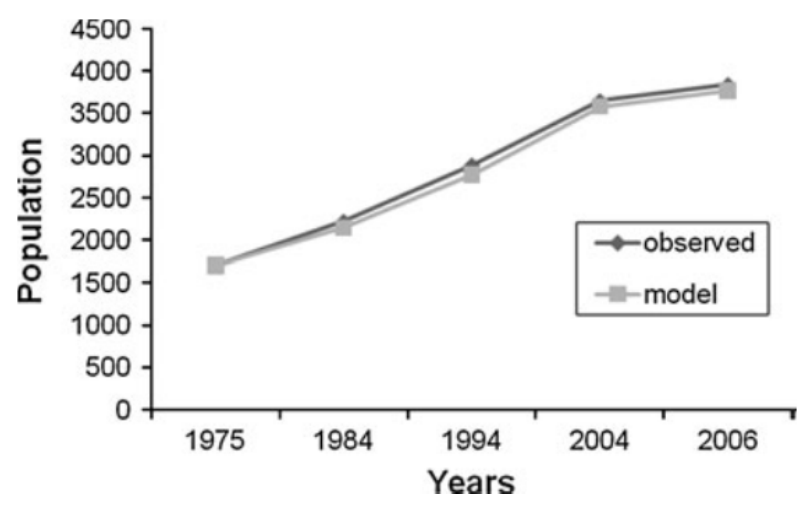

Figure 6 Comparison of simulated and actual population size 


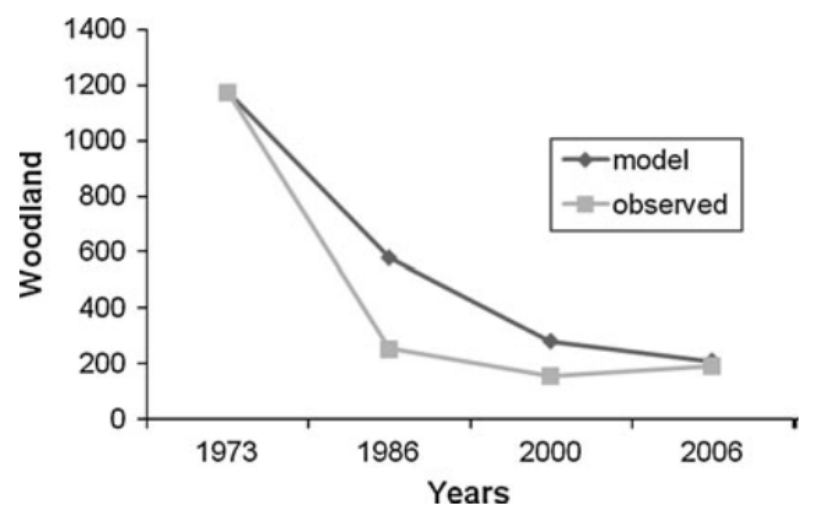

Figure 7 Comparison of simulated and actual woodland size in hectare

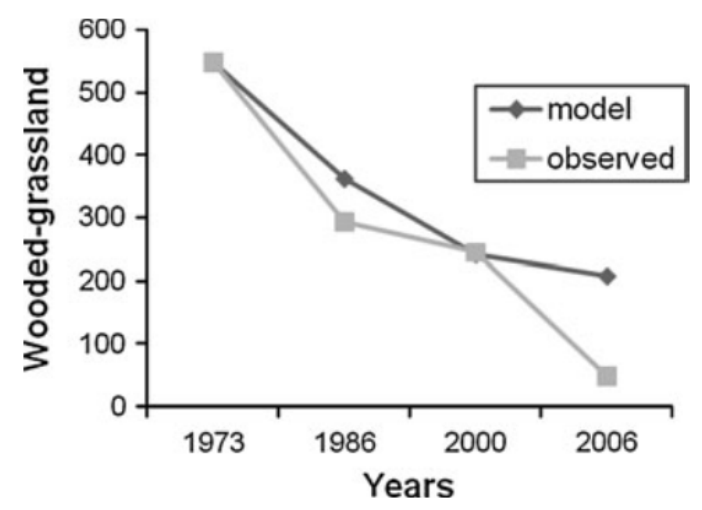

Figure 8 Comparison of simulated and actual wooded-grassland size in hectare

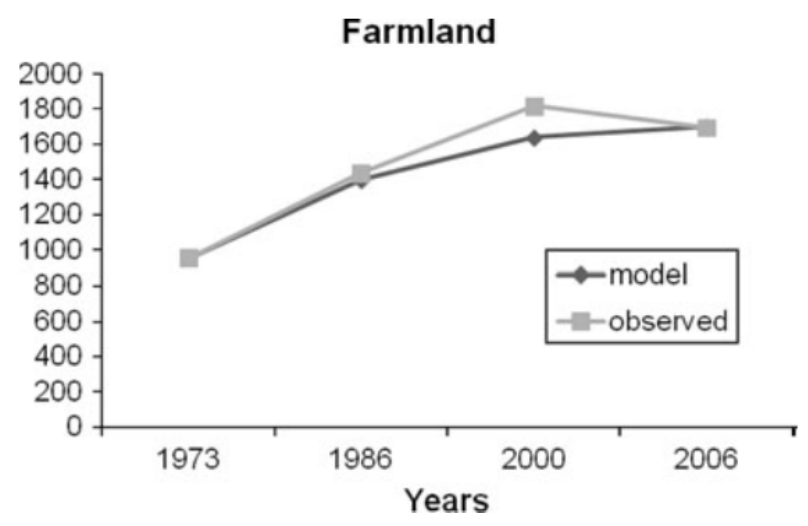

Figure 9 Comparison of simulated and actual farm size in hectare

\section{Discussion}

The tested model, STELLA, provides a basis for better understanding of socio-economic and environmental interactions. The model was built based on assumed relationships between 
different variables. The outcome of a simulation is entirely dependent on those relationships and the input data. Therefore, any output always needs to be analyzed in relation to those input assumptions. The use of a simulation model to predict the future development of the dynamic system under various conditions (or to study what input data generate a certain desired output) is important in developing effective strategies. There are many examples of similar system models that could contribute to the environmental management practices (Hellde'n 2008; Kassa et al. 2009; Sandewall and Nilsson 2001; Sayer et al. 2007; Ste'phenne and Lambin 2001). A participatory approach in scenario modeling is also an excellent platform for discussing strategies among different concerned stakeholders. If research data on historical trends are available it adds quality to the discussion on future developments.

We emphasize that a simulation model is not a forecasting instrument but a planning and analysis tool. It generates questions to be asked rather than direct answers. If a scenario suggests that farmers need to convert a certain cropland to woodland the question would be what efforts, resource inputs or strategies are required to achieve that. If that is not possible the question would be what other strategies could achieve an acceptable result. A more technical type of questions would be if the scenario or even the model accurately responds to or describes to the real world changes or if the model needs to be adjusted. One simple example of the later could be changes in birth rate as a result of "family planning" which may not happen instantly but change gradually over time.

In our model testing, it was not possible to undertake a strict statistical evaluation of the model because of the nature of the input data sets that encompasses a few separate years only. Therefore, instead of calculating error variance we used a graphical approach. The simulation outcomes are rough indications rather than very precise predictions. Validation with the historical development of some of the variables indicates that the model responds to key input variables more or less in a correct way.

The relationship between population growth and environmental changes is still an area of active debate (Alexandratos 2005; Carr et al. 2005; Grau et al. 2008; Jha and Bawa 2006; Nyssen et al. 2004). In Ethiopia, population growth increases the demand for arable land and encourages the conversion of forests to agriculture. It also increases the demand for wood. The 
link between population growth and land degradation are thought to be very strong (Bishaw 2001; Dessie and Christiansson 2008; Feoli et al. 2002; Hans et al. 2005; Taddese 2001; Teketay 2001). A previous study of land-use dynamics in the study area documented rapid population growth, declining crop productivity and rapid deforestation (Garedew et al. 2009). In the present study, the output of the simulation indicates a further rapid population growth, declining farm size and worsening environmental degradation and socio-economic conditions if "business as usual' continues. However, through strategies such as those indicated in the other scenarios, there could be an opportunity to reverse environmental degradation and reduce population growth. It requires, however among other things, that farmers are motivated to participate in increasing the forest in the landscape and that the government actively promotes family planning, health, education, micro-finance, securing of land property rights and sustainable natural resource management. There are encouraging experiences of natural resource restoration (flora, fauna and soil) through local people participation in different degraded dry-land regions of Ethiopia and other developing countries (Lamb et al. 2005; Mengistu et al. 2005; Verdoodt et al. 2009). A scenario based study in a forested part of Ethiopia suggested that participatory forest management (PFM) could provide higher forest cover and more sustainable household incomes for the local community (Kassa et al. 2009).

In southern and eastern African countries, farm sizes have been declining over time and a quarter of the agricultural households are controlling less than 0.10 hectares per capita (Jayne et al. 2003). In Ethiopia, the availability of land suitable for agriculture is shrinking due to land degradation, while the amount of land required to feed the growing population is steadily increasing (Haile 2004; Teketay 2001). Food security continues to deteriorate, the country has not been food self-sufficient for the last 3 decades and the gap has been filled by food-aid (Kirwan and McMillan 2007). In the present study, household farm size could decline due to population growth. As a result, low per capita income in the households is a major hindrance in providing adequate food to the members in the household. Household food security is likely deteriorating severely if crop productivity per unit area is unable to improve simultaneously with the rapidly increasing population. Informants have been mentioned repeatedly that erratic rainfall and shortage of land for crop production contributes to the challenge faced by the people living in the study area. In this respect, improving agriculture and diversifying livelihood options can help to reduce people’s economic difficulties. 


\section{Conclusions}

The model predicts an extensive land-use change, largely based on both the decisions of the community and natural population growth. The study simulates rapid population growth, declining household farm size, declining household income, further deterioration of forest cover and worsening land degradation if current practices continue.

The outlined “'forest increase scenario'” suggests a pathway that might possibly improve the restoration of forest cover in the landscape and subsequently raising household income. It addresses a critical issue but is not an easy way to go, which in practice requires the right decisions, confidence and interplay among farmers as well as government in order to bring back the forest.

The scenarios suggest that the level of population growth could be reduced with various strategies of family planning and education. This has an implication on the land-use patterns, the per capita household income and thereby on household food security. The amount of household income is largely dependent on the amount and distribution of rainfall and use of micro-finance. There was a strong relationship between rainfall variability and agricultural production.

Although, the simulation outcomes are predicted values, the study illustrates that the model can be used as a valuable supporting tool which can aid in the decision making processes in natural resource management. Local or regional planners can easily adapt the model and change variables following additional knowledge and discussions with interested stakeholders in the local area.

\section{Acknowledgments}

The authors are thankful to Professor Bruce M. Campbell and Dr. Neil Collier for their helpful professional support and Neil Cory editing the paper. We would like to thank the farmers and field-guides for their valuable participation and time. Special thanks go to Wondo Genet College of Forestry and Natural Resources and the Swedish International Development Agency (Sida) for financing the study.

\section{References}


Adams WM, Aveling R, Brockington D, Dickson B, Elliott J, Hutton J, Roe D, Vira B, Wolmer W (2004) Biodiversity Conservation and the Eradication of Poverty. Science 306:11461149.

Alexandratos N (2005) Countries with Rapid Population Growth and Resource Constraints: Issues of Food, Agriculture, and Development. Population and Development Review 31:237-258.

Amsalu A, de Graaff J (2006) Farmers' views of soil erosion problems and their conservation knowledge at Beressa watershed, Central highlands of Ethiopia. Agriculture and Human Values 23:99-108

Argaw M. (2005) Forest conversion, soil degradation, farmers' perception nexus: implications for sustainable land use in the south-west of Ethiopia. PhD thesis, University of Bonn.

Bishaw B (2001) Deforestation and Land Degradationin the Ethiopian Highlands: A Strategy for Physical Recovery. Northeast African Studies 8:7-25.

Bogale A, Taeb M, Endo M (2006) Land ownership and conflicts over the use of resources: implication for household vulnerability in eastern Ethiopia. Ecological Economics 58:134-145

Campbell BM, Sayer J, Cowling R, Kassa H, Knight A, Sandker M, Suwarno A. (2008) The role of participatiory modelling in landscape approaches to reconcile conservation and development, IUCN and CIFOR.

Carr DL, Suter L, Barbieri A (2005) Population Dynamics and Tropical Deforestation: State of the Debate and Conceptual Challenges. Population \& Environment 27:89-113.

Chan K, Pringle R, Ranganathan J, Boggs C, Chan Y, Ehrlich P, Haff P, Heller N, Al-Khafaji, K MD (2007) When agendas collide: human welfare and biological conservation. Conservation Biology 21:59-68.

Costanza R, Voinov A (2001) Modeling ecological and economic systems with STELLA: Part III. Ecological Modelling 143:1-7. 
Crewett W, Bogale A, Korf B. (2008) Land Tenure in Ethiopia: Continuity and Change, Shifting Rulers, and the Quest for State Control. CAPRi Working Paper 91. Washington, DC: International Food Policy Research Institute, pp. 30.

Deininger K, Ayalew D, Holden S, Zevenbergen J (2008) Rural Land Certification in Ethiopia: Process, Initial Impact, and Implications for Other African Countries. World Development 36:1786-1812.

Dessie G, Christiansson C (2008) Forest Decline and Its Causes in the South-Central Rift Valley of Ethiopia: Human Impact over a One Hundred Year Perspective. Ambio 37:263-271.

Doerr HM (1996) Stella ten years later: A review of the literature. International Journal of Computers for Mathematical Learning 1:201-224.

Ellis F. (2000) Rural Livelihoods and Diversity in Developing Countries Oxford University Press, Oxford.

Ellis F, Allison E. (2004) Livelihood diversification and natural resource access. Livelihood Support Programme Working Paper 9. Food and Agriculture Organization of the United Nations.

Ezra M (2001) Ecological degradation, rural poverty, and migration in Ethiopia: A contextual analysis Policy Research Division Working Paper no. 149. New York: Population Council.

Feoli E, Vuerich LG, Zerihun W (2002) Evaluation of environmental degradation in northern Ethiopia using GIS to integrate vegetation, geomorphological, erosion and socioeconomic factors. Agriculture, Ecosystems \& Environment 91:313-325.

Garedew E, Sandewall M, Söderberg U, Campbell B (2009) Land-Use and Land-Cover Dynamics in the Central Rift Valley of Ethiopia. Environmental Management 44:683694.

Grau HR, Gasparri NI, Aidew TM (2008) Balancing food production and nature conservation in the Neotropical dry forests of northern Argentina. Global Change Biology 14:985-997 
Geist HJ, Lambin EF (2002) Proximate Causes and Underlying Driving Forces of Tropical Deforestation. BioScience 52:143-150.

Haile S (2004) Population, Development, and Environment in Ethiopia. ECSP REPORT • ISSUE $10 \bullet 2004$.

Hans H, Kebede T, Gete Z ( 2005) The Implications of Changes in Population, Land Use, and Land Management for Surface Runoff in the Upper Nile Basin Area of Ethiopia. Mountain Research and Development 25 147-154.

Hartemink AE, Veldkamp T, Bai Z (2008) Land Cover Change and Soil Fertility Decline in Tropical Regions. Turkish Journal of Agriculture and Forestry 32:195-213.

Helldén U (2008) A coupled human-environment model for desertification simulation and impact studies. Global and Planetary Change 64:158-168.

High Performance Systems Inc. (1996) STELLA Software Technical Documentation.

Hutton J, Adams WM, Murombedzi JC (2005) Back to the barriers? Changing narratives in biodiversity conservation. Forum for Development Studies 2:341-370

Jayne TS, Yamano T, Weber MT, Tschirley D, Benfica R, Chapoto A, Zulu B (2003) Smallholder income and land distribution in Africa: implications for poverty reduction strategies. Food Policy 28:253-275.

Jha S, Bawa KS (2006) Population growth, human development, and deforestation in biodiversity hotspots. Conservation Biology 20:906-912

Kassa H, Campbell B, Sandewall M, Kebede M, Tesfaye Y, Dessie G, Seifu A, Tadesse M, Garedew E, Sandewall K (2009) Building future scenarios and uncovering persisting challenges of participatory forest management in Chilimo Forest, Central Ethiopia. Journal of Environmental Management 90:1004-1013.

Kirwan BE, McMillan M (2007) Food Aid and Poverty. American Journal of Agricultural Economics 89:1152-1160. 
Lamb D, Erskine PD, Parrotta JA (2005) Restoration of degraded tropicat forest landscapes. Science 310:1628-1632.

Lambin EF, Geist HJ, Lepers E (2003) Dynamics of land-use and land-cover change in Tropical regions. Annual Review of Environment and Resources 28:205-41.

Mahmud Y, Mekonnen A, Kassie M, Pender J. (2007) Cost of Land Degradation in Ethiopia: A critical review of past studies, EfD/WB.

Mengistu T, Teketay D, Hultén H, Yemshaw Y (2005) The Role of Communities in Closed Area Management in Ethiopia. Mountain Research and Development 25:44-50.

MoFED (2007) Ethiopia: Building on Progress: A Plan for Accelerated and Sustained Development to End Poverty (PASDEP). Annual Progress Report 2006/07, Ministry of Finance and Economic Development (MoFED), Addis Ababa. pp. 141.

Nyssen J, Poesen J, Moeyersons J, Deckers J, Haile M, Lang A (2004) Human impact on the environment in the Ethiopian and Eritrean highlands—a state of the art. Earth-Science Reviews 64:273-320

Nyssen J, Poesen J, Deckers J (2009) Land degradation and soil and water conservation in tropical highlands. Soil \& Tillage Research 103:197-202.

Robbins P, McSweeney K, Waite T, Rice J (2006) Even conservation rules are made to be broken: implications for biodiversity. Environmental Management 37:162-169.

Romero C, Andrade G (2004) Internation conservation organizations and the fate of local tropical conservation initiatives. Conservation Biology 18:578-580

Sanderson S, Redford K (2003) Contested relationships between biodiversity conservation and poverty alleviation. Oryx 37:389-390.

Sandewall M, Nilsson NE (2001) The Area Production Model: A tool and concept for sustainable land-use and forest-resource management. Journal of Environmental Management 62:415-427. 
Sayer JA, Campbell BM. (2004) The science of sustainable development: local livelihoods and the global environment Cambridge University Press, Cambridge, UK.

Sayer J, Campbell B, Petheram L, Aldrich M, Perez M, Endamana D, Dongmo Z-L, Defo L, Mariki S, Doggart N, Burgess N (2007) Assessing environment and development outcomes in conservation landscapes. Biodiversity and Conservation 16:2677-2694.

Segele ZT, Lamb PJ (2005) Characterization and variability of Kiremt rainy season over Ethiopia. Meteorology and Atmospheric Physics 89:153-180.

Singh S (2008) Social challenges to integrating conservation and development: the case of wildlife use in Laos. Society and Natural resources 21:952-955

Stéphenne N, Lambin EF (2001) A dynamic simulation model of land-use changes in Sudanosahelian countries of Africa (SALU). Agriculture, Ecosystems and Environment 85:145161.

Sunderland T, Ehringhaus C, Campbell B (2008) Conservation and development in tropical forest landscapes: a time to face the trade-offs? Environmental Conservation 34:276-279

Taddese G (2001) Land degradation: A challenge to Ethiopia. Environmental Management 27:815-824.

Tegenu T (2003) Socio-economic and Environmental Effects of Age Transition in Ethiopia, 1950-2000. Institute for Future Studies Stockholm. Paper presented at the First International Conference on the Ethiopian Economy, Addis Ababa.

Teketay D (2001) Deforestation, Wood Famine, and Environmental Degradation in Ethiopia's Highland Ecosystems: Urgent Need for Action. Northeast African Studies 8:53-76.

UNFCCC. (2007) Climate change: impacts, vulnerabilities and adaptation in developing countries United Nations Framework Convention on Climate Change (UNFCCC), Bonn, Germany. 
United Nations Population Division (2009) Population Division of the Department of Economic and Social Affairs of the United Nations Secretariat, World Population Prospects: The 2008 Revision. http://esa.un.org/unpp. Accessed 13 August 2009.

Verdoodt A, Mureithi SM, Ye L, Ranst EV (2009) Chronosequence analysis of two enclosure management strategies in degraded rangeland of semi-arid Kenya. Agriculture, Ecosystems and Environment 129:332-339. 